\title{
Effect of Technological Parameters on Energetic Efficiency When Planar Milling Heat-treated Oak Wood
}

\author{
Peter Koleda, ${ }^{\mathrm{a}, *}$ Štefan Barcík, ${ }^{\mathrm{a}}$ Michal Korčok, ${ }^{\mathrm{a}}$ Zuzana Jamberová, ${ }^{\mathrm{a}}$ and \\ Vadzim Chayeuski ${ }^{b}$
}

\begin{abstract}
Measuring the energy consumption and evaluating the efficiency of machining processes is necessary for their optimization and for implementation of cleaner production. The final product quality and the machining process of woodworking are of great interest. The properties of thermally modified wood make it more resistant to fungi, moulds, and ligniperdous insects than natural wood, so it is increasingly used in interior and exterior spaces. This study examined the energy demand of the milling of heat-treated oak wood (Quercus petraea) by ThermoWood® technology. The investigated technological parameters were thermal modification temperature $\left(160^{\circ} \mathrm{C}, 180^{\circ} \mathrm{C}, 200^{\circ} \mathrm{C}\right.$, and $\left.220^{\circ} \mathrm{C}\right)$, cutting

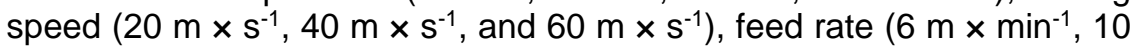
$\mathrm{m} \times \mathrm{min}^{-1}$, and $\left.15 \mathrm{~m} \times \mathrm{min}^{-1}\right)$, and the material of the cutting tool. As the temperature of the thermal modification increased, the cutting power decreased due to a chemical degradation due to heating and reduced wood density. The lowest energy consumption was observed for the milling of wood treated at $220^{\circ} \mathrm{C}$ with a cutting speed of $20 \mathrm{~m} \times \mathrm{s}^{-1}$, and a feed rate of $6 \mathrm{~m} \times \mathrm{min}^{-1}$.
\end{abstract}

Keywords: Energetic efficiency; Cutting power; Milling ThermoWood®; Quercus petraea

Contact information: a: Department of Manufacturing and Automation Technology, Faculty of Environmental and Manufacturing Technology, Technical University in Zvolen, Studentská 26, Zvolen 960 01 Slovakia; b: Belarusian State Technological University, Department of Physics, 13a, Sverdlova Str., Minsk 220006 Republic of Belarus; *Corresponding author: peter.koleda@tuzvo.sk

\section{INTRODUCTION}

Wood and its machining are of interest to research from various perspectives. Technical and technological parameters of machining as well as wood treatment technology are examined in terms of the electricity consumption of individual construction mechanisms and when turning on the relevant functions of the woodworking machine. Zein (2012) and Sudarsan et al. (2010) show in the results of machining centre energy consumption research that the energy for the cooling and control system can be considered a constant value, and there is a strong correlation between the input power to the power supply module and the input power to the main spindle drive. The drive of the positioning servo system consumes several times less energy than the drive of the main spindle of the machine tool (Liu et al. 2017).

Several models have been developed to predict and optimize energy consumption, most commonly involving milling and turning operations (Moradnazhad and Unver 2017; Shi et al. 2019). In contrast with the production capacity and the quality of the created surface, information on energy demands reduces production costs (Mickovic and Wouters 2020). 
Scientific works have experimentally investigated the influence of technicaltechnological parameters on cutting power in the milling of natural and thermally modified wood (Barcik et al. 2010; de Moura et al. 2011; Barcík and Gašparík 2014; Tu et al. 2014). Specifically mentioned trees are summer oak (Quercus robur L.), winter oak (Quercus petraea (Matt.) Liebl.), Norway spruce (Picea abies (L.) H. Karst.), and red meranti (Shorea acuminata Dyer) (Koleda et al. 2018a; Korčok 2020; Šulek 2020). The cutting power increased as a result of the increasing cutting speed. In terms of cutting edge wear and optimal use of machinery, it can be stated that the optimal cutting speed is approximately $40 \mathrm{~m} \times \mathrm{s}^{-1}$. Ispas et al. (2016) showed that the cutting power increased for all investigated beechwood samples due to increasing cut depths, revolutions (3300 and $\left.4830 \mathrm{~min}^{-1}\right)$, and feed speeds $\left(4.5,9,13.5,18\right.$, and $\left.22.5 \mathrm{~m} \times \mathrm{min}^{-1}\right)$.

Kubš et al. (2016, 2017), based on their research of beech and pine wood machining, have shown that the most important factors affecting the cutting power during plane milling are cutting speed, face angle of the milling cutter face, and feed speed. Larger differences in power have been demonstrated at different face angles of the milling cutter.

Krauss et al. (2016) conducted a study to analyse the impact of cut depth $(0.5,1.0$, and $2.0 \mathrm{~mm}$ ) of the pine samples on the cutting power during plane milling. The results of the research showed that the cutting power during the plane milling of wood increases due to the increasing depth of cut. Koleda and Hrčková (2018) measured the dimensions of fractional particles resulting from the milling and predicted the tool wear.

Heat-treated wood has been extensively manufactured for more than 10 years, and its production has been introduced to many Western European countries in response to the changing chemical wood treatment legislation (International ThermoWood Association 2003). Finland pioneered the production of thermally modified wood with ThermoWood® in 1990. Later, ThermoWood $®$ began to be produced in the Netherlands, Germany, Austria, and France (International ThermoWood Association 2003; Gaff et al. 2015). The primary aim of thermally modifying wood is to prepare a material that balances the following benefits: a lower hygroscopicity; higher dimensional stability; higher resistance to wood-decaying and discolouring fungi, moulds, and ligniperdous insects; maintaining or improving the aesthetics (colour, minimal cracks, gloss, texture, etc.); and preservation or improvement of the mechanical properties (strength hardness, stiffness, etc.) (Požgaj et al. 1997; Bengtsson et al. 2003; Boonstra et al. 2007; Boonstra 2008; Niemz et al. 2010; Barcík and Gašparík 2014; Aytin et al. 2019).

It is well known that, apart from the decrease of mechanical properties in the process of thermal modification, the weight and density of wood are also decreased, which makes the wood more brittle (International ThermoWood Association 2003; Gunduz et al. 2009; Maulis 2009; Koleda et al. 2018b; Korčok et al. 2018). Thermal treatment changes the chemical properties of wood, e.g. the cell wall saturation limit (Hrčka et al. 2020). Granular analyses of wood dust in the sanding process indicate that decreases in wood density cause a decrease in the number of wood dust particles (Očkajová and Banski 2009; Očkajová et al. 2016).

This article evaluated the effect of the technology (i.e., temperature) of heat treatment, rake angle, feed rate, and cutting speed on the efficiency of energy usage in the planar milling of oak wood. 


\section{EXPERIMENTAL}

\section{Materials}

Samples of $Q$. petraea wood with an average age of 107 years from Vlčí jarok (Budča, Slovakia) were used in the experiments. The samples were made via ThermoWood® technology at the Arboretum of the Faculty of Forestry and Wood Sciences (Czech University of Life Sciences in Prague, Czech Republic) in Kostelec nad Černými lesy in a LAC S400/03 type chamber (Katres, Říčany, Czech Republic). The mechanical woodworking of samples with the dimensions of $500 \mathrm{~mm} \times 110 \mathrm{~mm} \times 20 \mathrm{~mm}$ and their subsequent drying and heat treatment at temperatures of $160^{\circ} \mathrm{C}, 180{ }^{\circ} \mathrm{C}, 200{ }^{\circ} \mathrm{C}$, and 220 ${ }^{\circ} \mathrm{C}$ were performed using the technologies described by Hrčková et al. (2018) and Koleda et al. (2020). The samples were stored at a temperature of $10{ }^{\circ} \mathrm{C}$. The samples remained in the chamber until they cooled to $60{ }^{\circ} \mathrm{C}$; then, they were removed. The process of temperature changing itself (i.e., heating, temperature exposure, or cooling) in time is illustrated in Fig. 1. The density measurements and cutting conditions were as in Koleda et al. (2018). The samples were milled on a lower spindle milling machine FVS (Czechoslovakia Music Instruments, Hradec Králové, Czech Republic) and feeding mechanism ZMD 252/137 (Frommia, Fellbach, Germany) at the Technical University in Zvolen (Zvolen, Slovakia). Table 1 shows the technical parameters of the milling machine. The device for the power consumption measurement at milling consisted of a UNIFREM 400 007M frequency converter (Vonsch, Slovakia) that controls the speed of a three-phase asynchronous motor (Fig. 2). Another part of the frequency converter is a sine filter SKY3FSM25 that smoothed the impulse voltage from the inverter to approximate the ideal sinusoidal phase with a phase shift of $120^{\circ}$. The frequency converter evaluated the active motor input without losses and the engine power from the current, voltage, and efficiency of the motor. The cutting power was calculated as the difference between power when milling and power when idling.

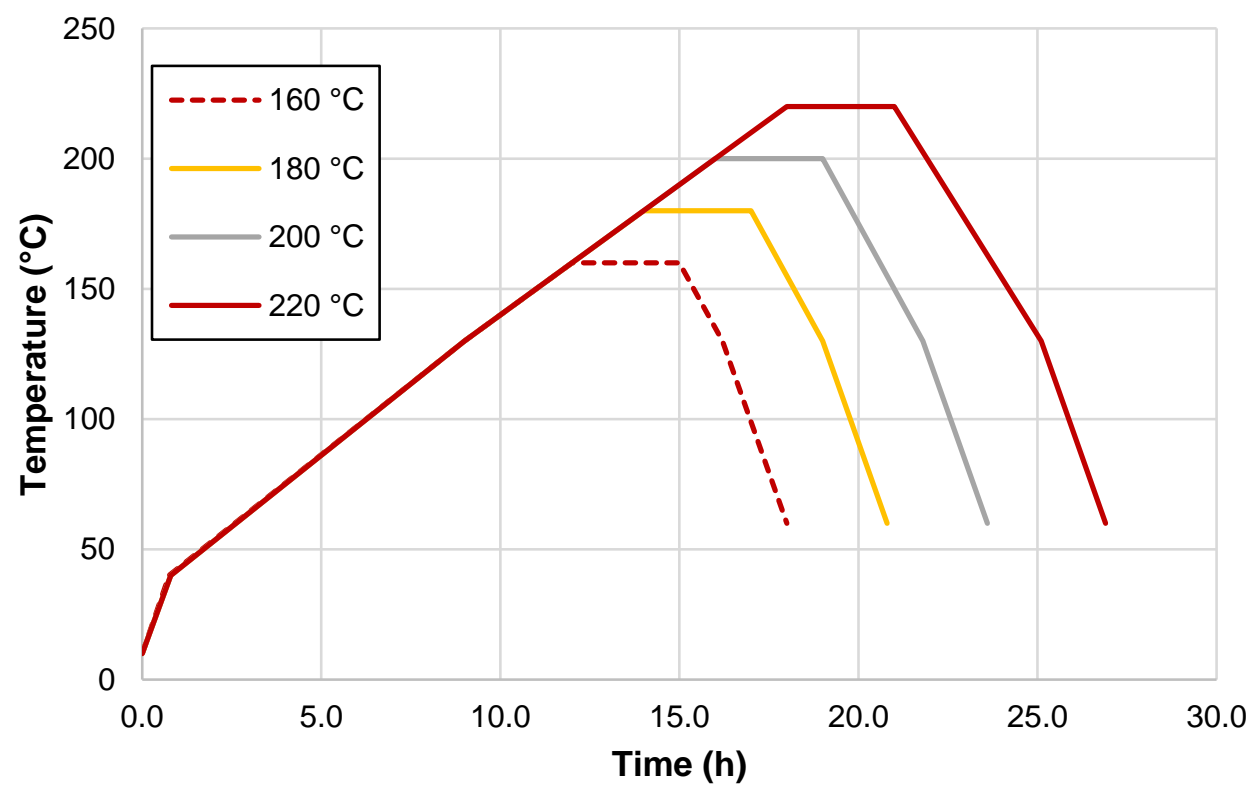

Fig. 1. Durations and temperatures of heat-treatment of oak wood (Quercus petraea) 
Table 1. Technical Parameters of the Lower Spindle Milling Machine FVS and the Feeder

\begin{tabular}{|c|c|c|c|}
\hline \multicolumn{2}{|c|}{ Lower Spindle Milling Machine (FVS) } & \multicolumn{2}{|c|}{ Feeder (Frommia ZMD 252/137) } \\
\hline Voltage System $(\mathrm{V})$ & 360 and 220 & Feed Range $\left(\mathrm{m} \times \mathrm{min}^{-1}\right)$ & $2.5,10,15,20$, and 30 \\
\hline Frequency $(\mathrm{Hz})$ & 50 & Voltage $(\mathrm{V})$ & 380 \\
\hline Input $(\mathrm{kW})$ & 4 & Speed $\left(\mathrm{m} \times \mathrm{min}^{-1}\right)$ & 2800 \\
\hline
\end{tabular}

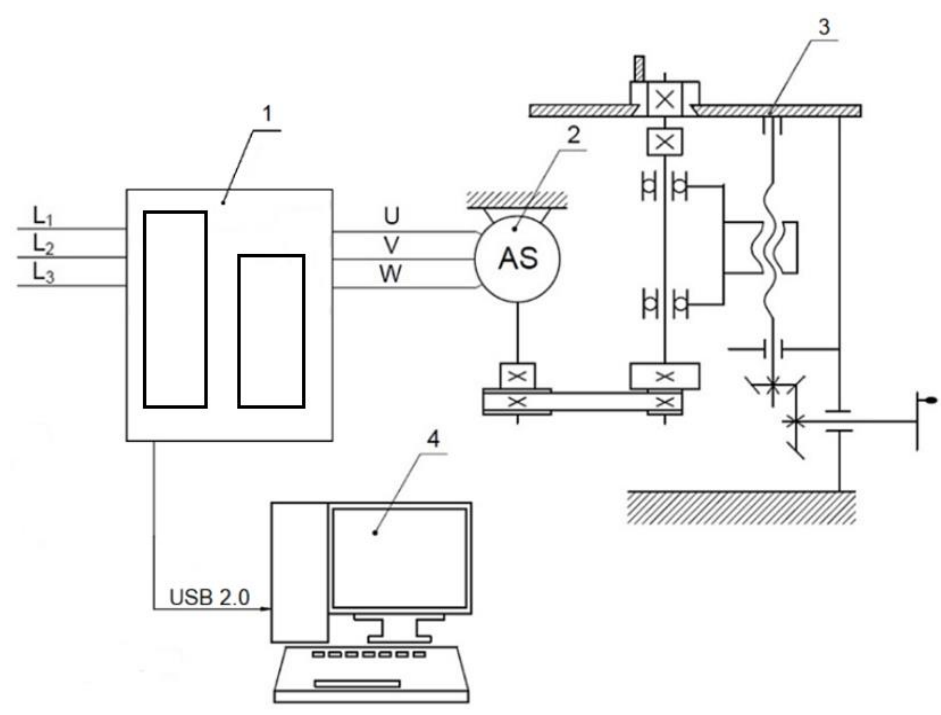

Fig. 2. Measuring apparatus for power measurement: (1) electrical device with frequency converter and sine filter; (2) asynchronous motor; (3) down milling cutter; (4) PC

A double-blade wood cutter block with rake angles $(\gamma)$ of $15^{\circ}, 20^{\circ}$, and $30^{\circ}$, and interchangeable blades were used for milling with a cutting depth of $1 \mathrm{~mm}$ (Fig. 3). The

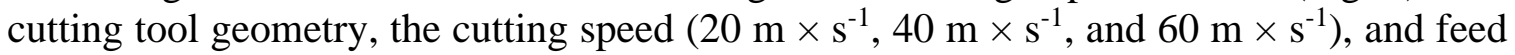
rate $\left(6 \mathrm{~m} \times \mathrm{min}^{-1}, 10 \mathrm{~m} \times \mathrm{min}^{-1}\right.$, and $\left.15 \mathrm{~m} \times \mathrm{min}^{-1}\right)$ were the same as those used by Koleda et al. (2018a). Three sets of knives were used when milling, which included knives induction hardened from material 19573 (Wood-B Ltd., Nové Zámky, Slovakia) (set 1), knives from steel HSS 18\% W with AlTiCrN coating (Belarusian Academy of Science, Minsk, Belarus) (set 2), and knives from MAXIMUM SPECIAL 55: 1985/5 steel (WoodB Ltd., Nové Zámky, Slovakia) (set 3). Measured data was processed using MS Excel (Microsoft Corporation, version 18.2008.12711.0, Redmond, WA, USA) and statistically evaluated by Statistica 12 (StatSoft, Tulsa, OK, USA).

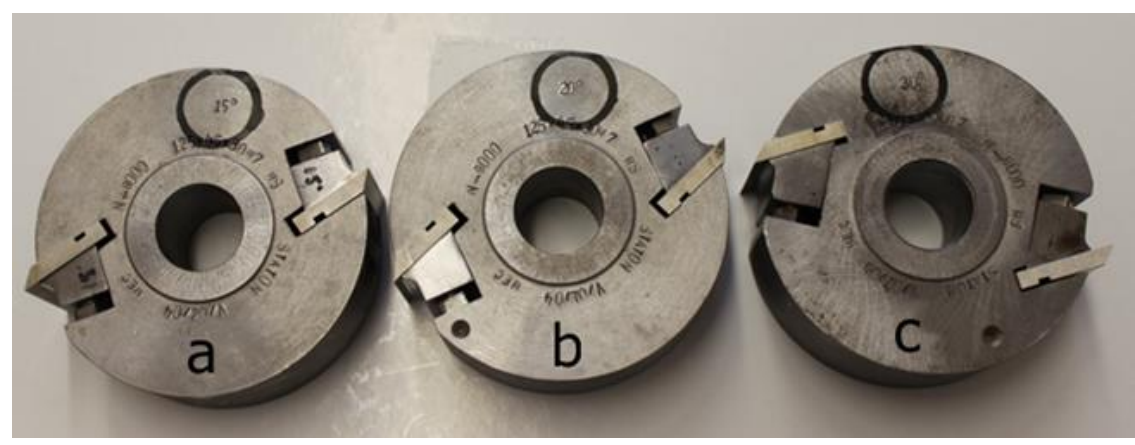

Fig. 3. Milling cutters with rake angles of (a) $15^{\circ}$, (b) $20^{\circ}$, and (c) $30^{\circ}$ 


\section{RESULTS AND DISCUSSION}

Figure 4 shows the density values of the samples. The density decreased with the increasing temperature of the heat treatment. The natural wood sample showed the highest density $\left(775.8 \mathrm{~kg} \times \mathrm{m}^{-3}\right)$. The thermally treated sample showed the lowest density at the highest temperature $\left(220{ }^{\circ} \mathrm{C}\right)$, which was a $21.51 \%$ decrease compared to an untreated sample. Thermal treatment made the wood more fragile. Hydrophilic functional groups began to disappear in the structures of the polysaccharides, lignin, and accompanying materials.

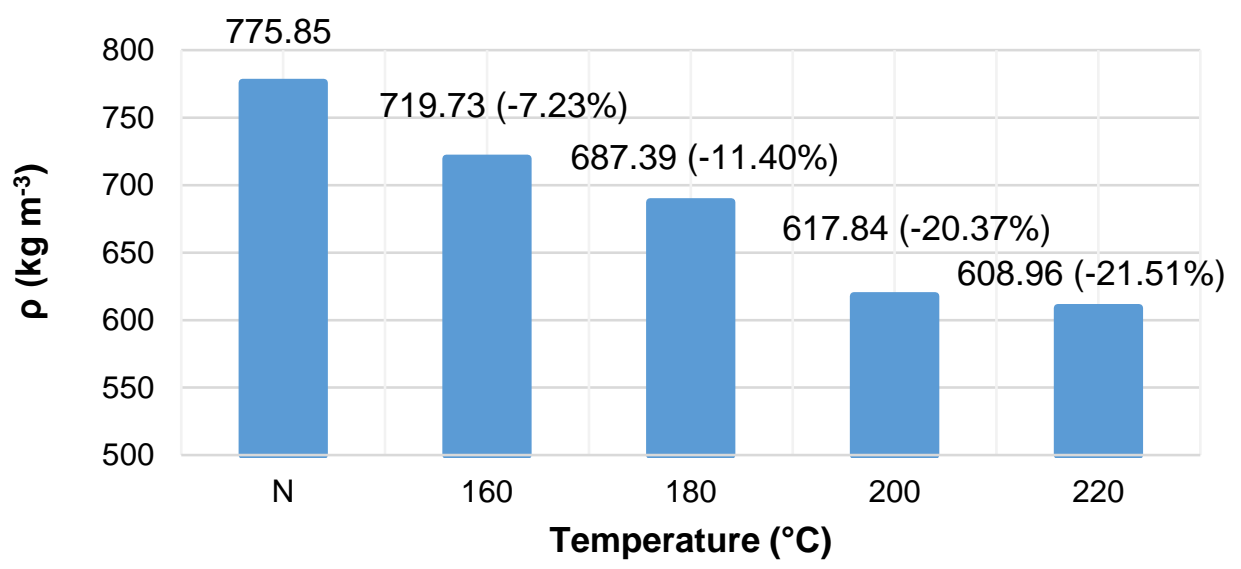

Fig. 4. Density and heat treatment temperature (the parentheses show the decrease compared to natural wood)

Table 2 shows the basic cutting power statistics depending on the thermal treatment temperature. As the temperature increased, the cutting power decreased. The highest cutting power was measured for the native wood and the lowest for the sample thermally treated at $220{ }^{\circ} \mathrm{C}$. The decrease was caused by a change in the structure of the wood and its chemical composition due to temperature, which was also reflected in its lower density.

As the experimental samples were extracted from different logs and were manipulated from different parts of the trunk, the structure of the examined samples influenced the power values recorded during milling. Further researching the heat transfers of thermally modified wood by a holography interferometer could help discover the values of the heat transfer coefficients (Černecký et al. 2013, 2017).

Table 2. Basic Statistics of Cutting Power and Heat Treatment Technology

\begin{tabular}{|c|c|c|c|c|c|c|}
\hline $\mathrm{T}\left({ }^{\circ} \mathrm{C}\right)$ & Number & $\begin{array}{c}\text { Average } \\
\text { Power }(\mathrm{W})\end{array}$ & Std. Dev. (W) & Error $(\mathrm{W})$ & $\begin{array}{c}-0.95 \% \\
\text { Interval }(\mathrm{W})\end{array}$ & $\begin{array}{c}+0.95 \% \\
\text { Interval }(\mathrm{W})\end{array}$ \\
\hline $\mathrm{N}$ & 5670 & 146.76 & 71.27 & 0.95 & 144.90 & 148.62 \\
\hline 160 & 5670 & 119.16 & 62.68 & 0.83 & 117.53 & 120.79 \\
\hline 180 & 5670 & 103.78 & 54.80 & 0.73 & 102.35 & 105.20 \\
\hline 200 & 5670 & 99.63 & 53.85 & 0.72 & 98.23 & 101.04 \\
\hline 220 & 5670 & 89.07 & 48.00 & 0.64 & 87.82 & 90.32 \\
\hline
\end{tabular}


Figure 5 shows the influence of the cutting tool on the cutting power depending on the temperature of the heat treatment without considering feed energy consumption (Koleda et al. 2020). Cutting tool set 2 resulted in the lowest energy consumption for all samples, where the cutting power decreased as the temperature increased. For cutting tool sets 1 and 3, the values were overlapping. The highest cutting power values were recorded with tool set 1 , whereby they overlapped with the cutting power values measured with set 3 . The different values were due to the wear and hardness of the material depending on the knife hardening technology, the coating of the blades, and their grinding before coating.

As the temperature increased (thermally modified wood), the power decreased during milling. The reduction in milling power consumption is reported in Krauss et al. (2016) due to the milling of thermally treated pine wood. This is related to a change in the chemical composition and structure of the wood and a change in its density.

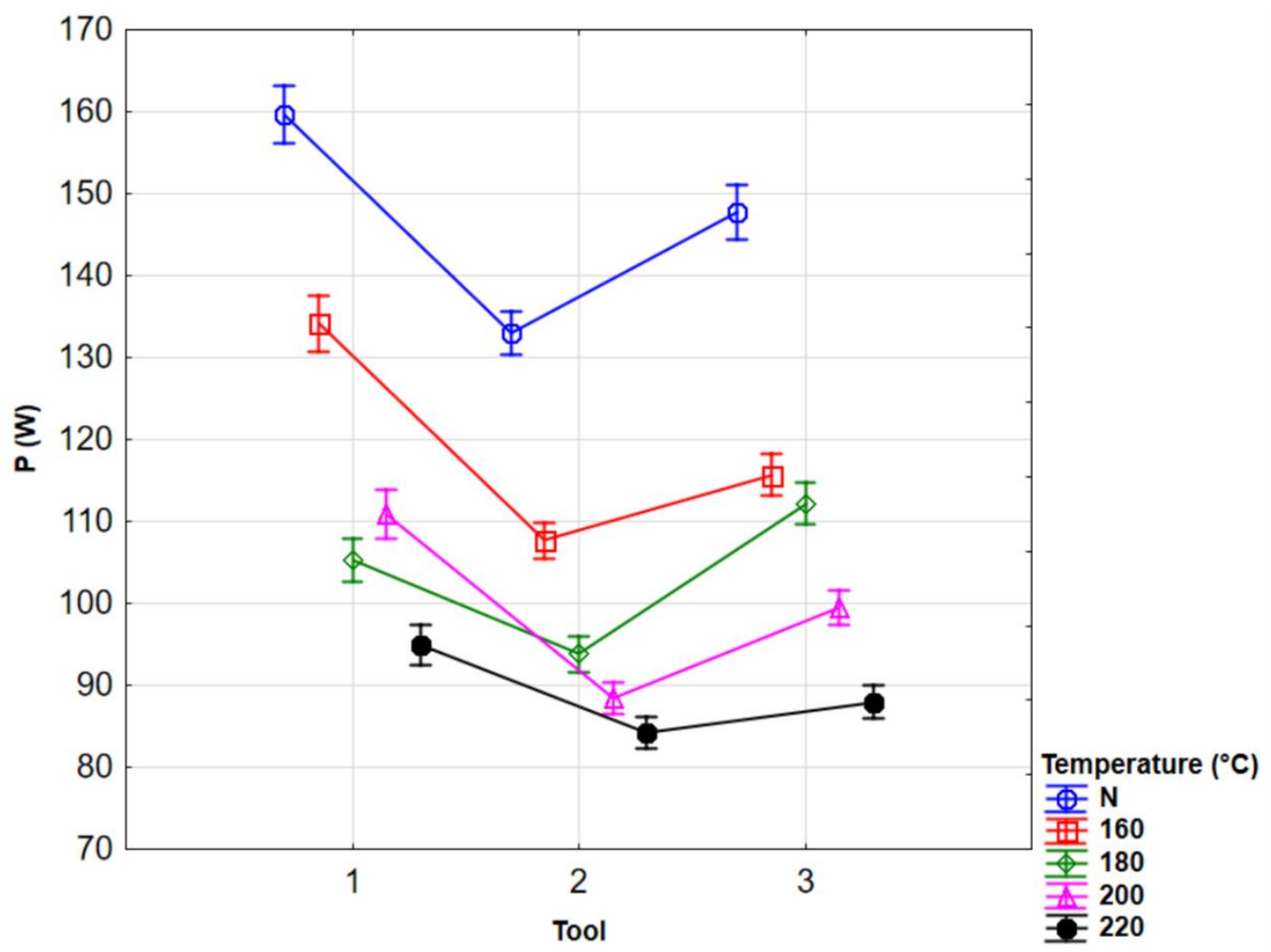

Fig. 5. Analysis of variance of cutting power depending on the heat treatment temperature and tool set

Table 3 shows the basic statistics for cutting power depending on heat treatment and tool set. The highest average cutting power value $(159.65 \mathrm{~W})$ was observed for the native wood machined with tool set 1 . The lowest average cutting power value $(84.24 \mathrm{~W})$ was recorded for the thermally treated sample at $220^{\circ} \mathrm{C}$, which was machined with the tool set 2 .

Figure 6 shows the analysis of variance of cutting power versus the temperature of thermal modification and rake angle. As the rake angle increased, the cutting power decreased. For all heat treatment technologies, the lowest cutting power was achieved at a rake angle of $30^{\circ}$. The lowest value $(69.1 \mathrm{~W})$ was measured at the rake angle of $30^{\circ}$ for the 
sample treated at $220{ }^{\circ} \mathrm{C}$, and the highest value $(183.6 \mathrm{~W})$ was measured at the rake angle of $15^{\circ}$ for the untreated sample. This was due to a change in the force conditions for chip separation and a reduction in the cutting force required to separate the material.

Table 3. Basic Statistics of Cutting Power Depending on Rake Angle

\begin{tabular}{|c|c|c|c|c|c|c|}
\hline $\begin{array}{c}\gamma \\
\left({ }^{\circ}\right)\end{array}$ & Number & $\begin{array}{c}\text { Average Power } \\
(\mathrm{W})\end{array}$ & $\begin{array}{c}\text { Std. Dev. } \\
(\mathrm{W})\end{array}$ & Error $(\mathrm{W})$ & $\begin{array}{c}-0.95 \% \\
\text { Interval }(\mathrm{W})\end{array}$ & $\begin{array}{c}+0.95 \% \\
\text { Interval }(\mathrm{W})\end{array}$ \\
\hline 15 & 9450 & 130.37 & 64.28 & 0.66 & 129.08 & 131.67 \\
\hline 25 & 9450 & 119.36 & 66.37 & 0.68 & 118.02 & 120.69 \\
\hline 30 & 9450 & 85.30 & 43.46 & 0.44 & 84.42 & 86.17 \\
\hline
\end{tabular}

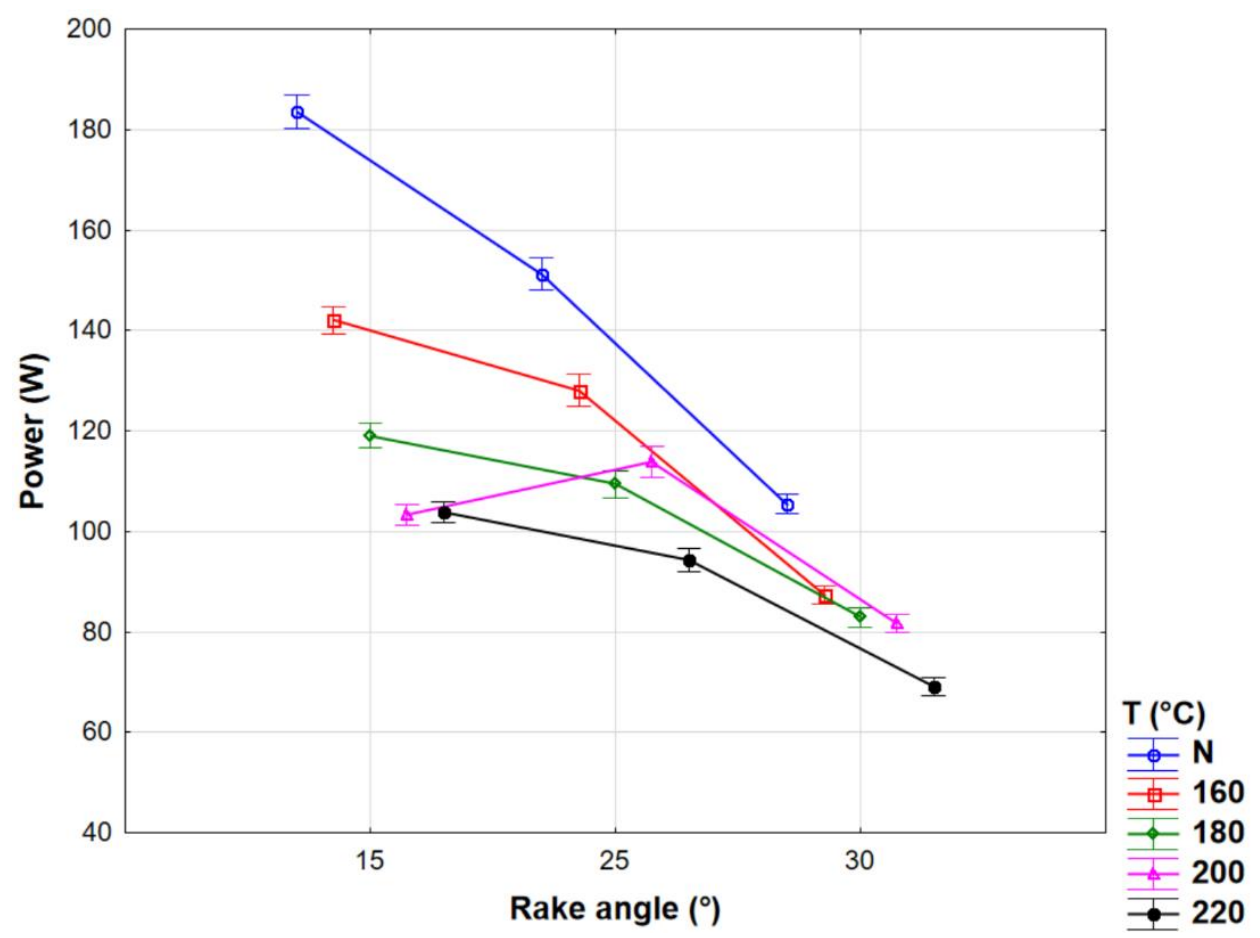

Fig. 6. Analysis of variance of cutting power dependence on heat treatment temperature and rake angle

Figure 7 shows the analysis of variance of cutting power depending on the rake angle and heat treatment temperature for each tool set. The lowest values (average power $=74.3 \mathrm{~W}$ ) were measured using tool set 1 at a rake angle of $30^{\circ}$, and the highest (average power $=166.7 \mathrm{~W}$ ) were measured using the same tool set 1 at a rake angle of $25^{\circ}$.

Table 4 shows the basic statistics of cutting power depending on cutting speed. As cutting speed increased, the cutting power increased. Figure 8 shows the analysis of variance of cutting power versus temperature and cutting speed. Increased cutting speed resulted in increased cutting power, which was because cutting power is a product of elementary cutting force and cutting speed (Vasilko 2007). The highest cutting power $(201.02 \mathrm{~W})$ was measured for native wood at a cutting speed of $60 \mathrm{~m} \times \mathrm{s}^{-1}$, and the lowest cutting power $(47.71 \mathrm{~W})$ was observed for wood treated at $220{ }^{\circ} \mathrm{C}$ and a cutting speed of $20 \mathrm{~m}^{-1}$. For all heat treatment technologies, the highest cutting power was achieved at a cutting speed of $60 \mathrm{~m} \times \mathrm{s}^{-1}$, and the lowest cutting power was achieved at a cutting speed of $20 \mathrm{~m} \times \mathrm{s}^{-1}$. 


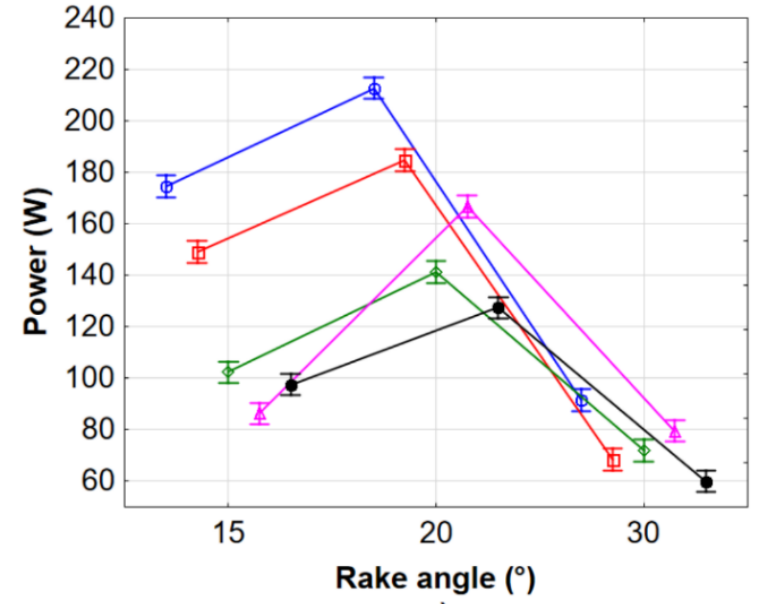

a)

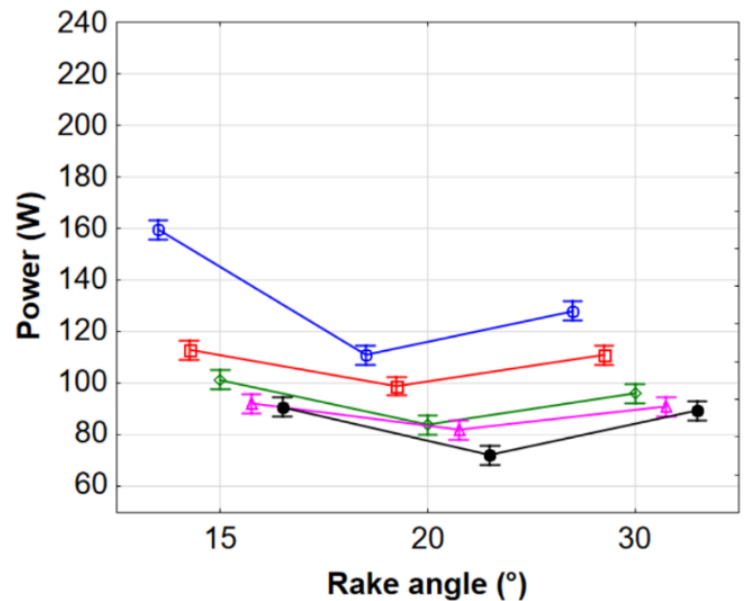

b)

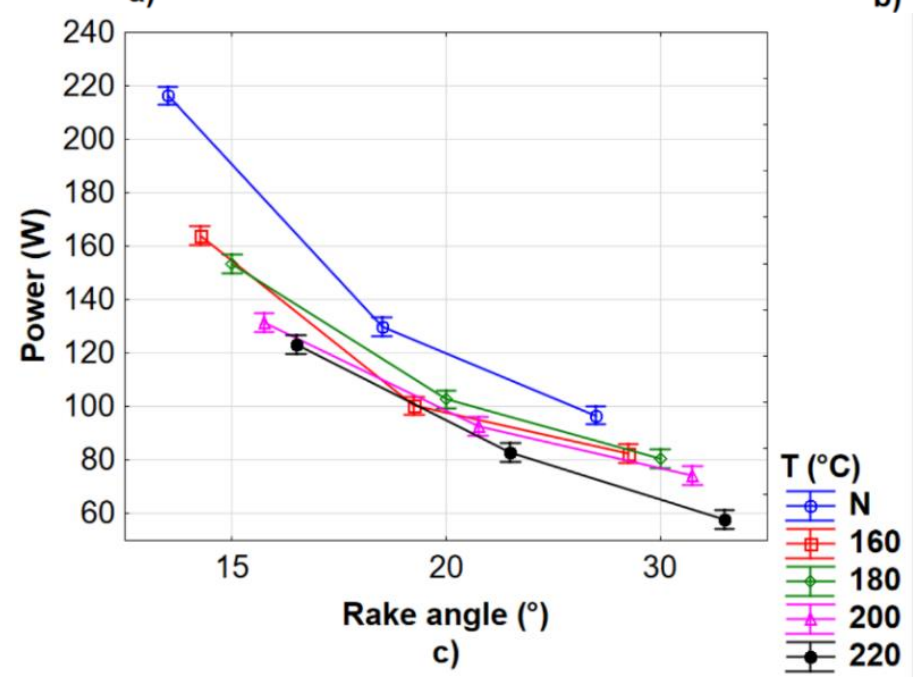

Fig. 7. Analysis of variance of cutting power dependence on rake angle and heat treatment temperature for tool set $1(a)$, set 2 (b), and set 3 (c)

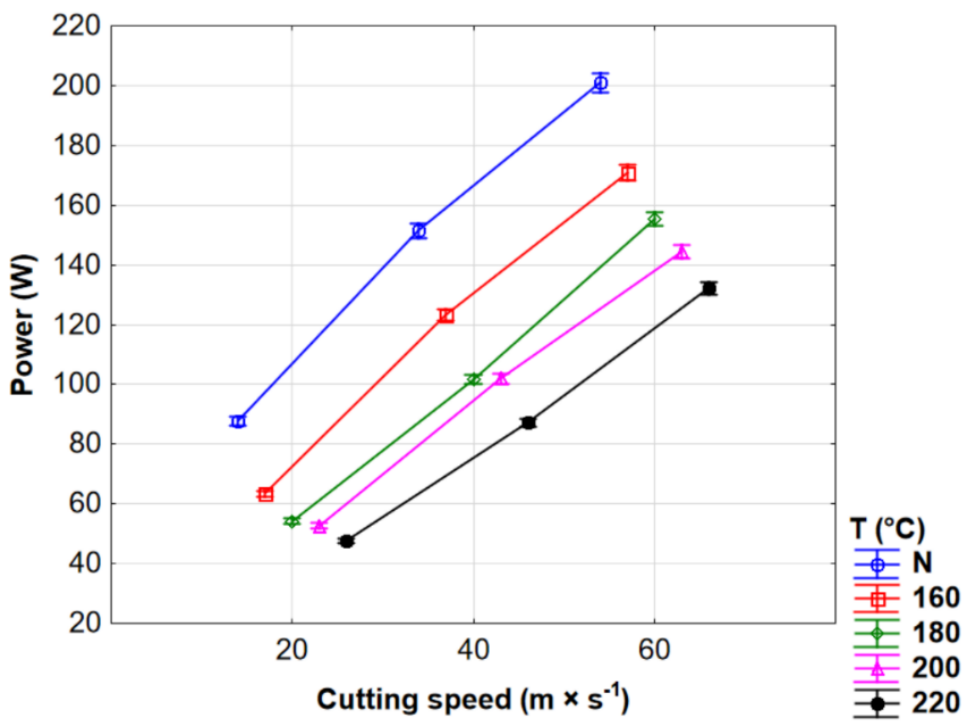

Fig. 8. Analysis of variance of cutting power depending on heat-treatment and cutting speed 
Table 4. Basic Statistics of Cutting Power Depending on Cutting Speed

\begin{tabular}{|c|c|c|c|c|c|c|}
\hline$v_{\mathrm{c}}\left(\mathrm{m} \times \mathrm{s}^{-1}\right)$ & Number & $\begin{array}{c}\text { Average } \\
\text { Power }(\mathrm{W})\end{array}$ & Std. Dev. (W) & Error $(\mathrm{W})$ & $\begin{array}{c}-0.95 \% \\
\text { Interval }(\mathrm{W})\end{array}$ & $\begin{array}{c}+0.95 \% \\
\text { Interval }(\mathrm{W})\end{array}$ \\
\hline 20 & 9450 & 61.15 & 26.93 & 0.27 & 60.61 & 61.69 \\
\hline 40 & 9450 & 113.11 & 45.99 & 0.47 & 112.18 & 114.04 \\
\hline 60 & 9450 & 160.76 & 61.04 & 0.62 & 159.53 & 162.00 \\
\hline
\end{tabular}

Figure 9 shows the analysis of variance of cutting power depending on cutting speed and heat-treatment temperature for each tool set. The lowest values (average power $=52.0$ W) were measured using tool set 2 at a cutting speed of $20 \mathrm{~m} \mathrm{x} \mathrm{s}^{-1}$, and the highest values (average power $=176.5 \mathrm{~W}$ ) were obtained using tool set 1 at a cutting speed of $60 \mathrm{~m} \mathrm{~s} \mathrm{~s}^{-1}$.

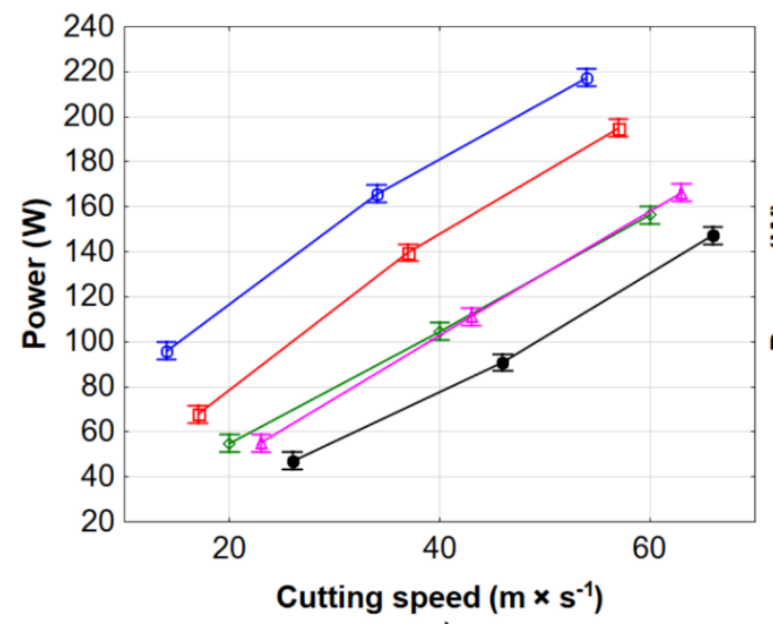

a)

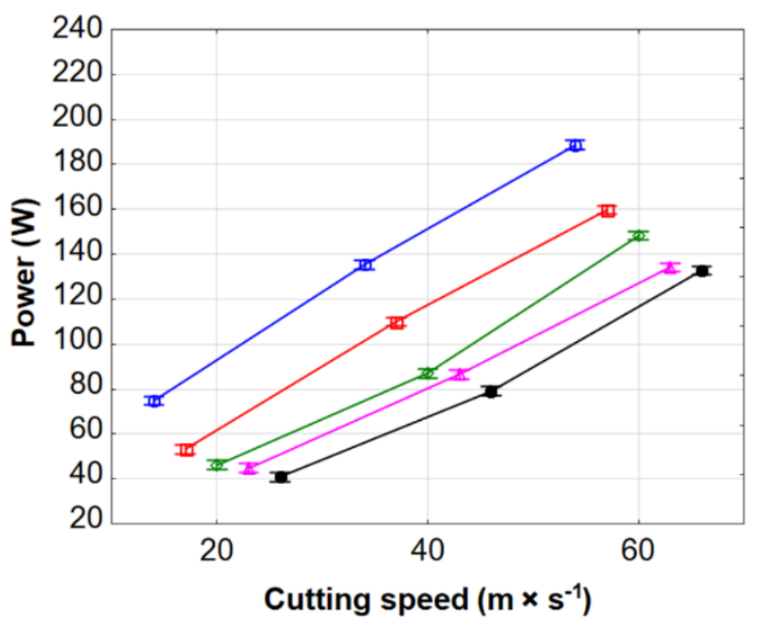

b)

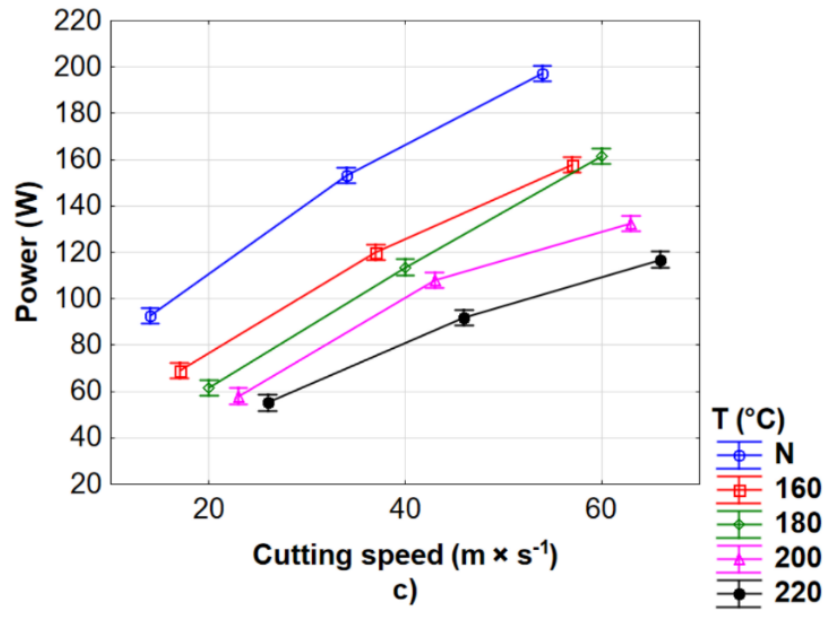

Fig. 9. Analysis of variance of cutting power depending on cutting speed and heat treatment temperature for tool set 1 (a), set 2 (b), and set 3 (c)

Table 5 shows the basic statistics of cutting power depending on feed rate. Figure 10 shows the analysis of variance of cutting power depending on temperature and feed rate. For each wood sample, the dependence of reduction of the cutting power on the reduction of the feed rate was demonstrated. This was due to the reduced amount of material removed at one time, reducing the feed rate. Therefore, the cutting force decreased. The lowest values of feed rate were measured for the sample heat-treated at $220{ }^{\circ} \mathrm{C}$, and the highest feed rate values were observed for the native sample. 
Table 5. Basic Statistics of Cutting Power Depending on Feed Rate

\begin{tabular}{|c|c|c|c|c|c|c|}
\hline$v_{f}\left(\mathrm{~m} \times \mathrm{min}^{-1}\right)$ & Number & $\begin{array}{c}\text { Average } \\
\text { Power }(\mathrm{W})\end{array}$ & Std. Dev. $(\mathrm{W})$ & Error $(\mathrm{W})$ & $\begin{array}{c}-0.95 \% \\
\text { Interval }(\mathrm{W})\end{array}$ & $\begin{array}{c}+0.95 \% \\
\text { Interval }(\mathrm{W})\end{array}$ \\
\hline 6 & 9450 & 101.82 & 56.16 & 0.58 & 100.69 & 102.96 \\
\hline 10 & 9450 & 111.10 & 61.52 & 0.63 & 109.86 & 112.35 \\
\hline 15 & 9450 & 122.11 & 66.23 & 0.68 & 120.78 & 123.45 \\
\hline
\end{tabular}

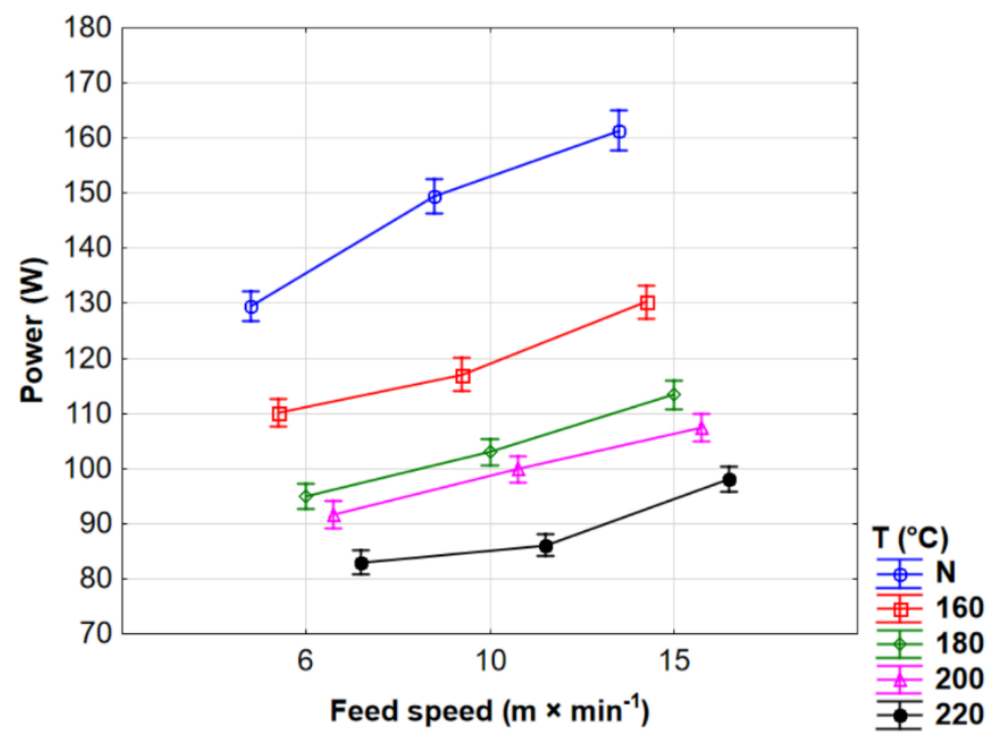

Fig. 10. Analysis of variance of cutting power depending on heat treatment temperature and feed rate

Figure 11 shows the analysis of variance of cutting power depending on the feed rate and heat treatment temperature for each tool set. The lowest values (average power $=$ $93.87 \mathrm{~W}$ ) were measured using tool set 2 at a feed rate of $6 \mathrm{~m} \times \mathrm{min}^{-1}$, and the highest values (average power $=128.9 \mathrm{~W}$ ) were measured using tool set 1 at a feed rate of $15 \mathrm{~m} \times$ $\min ^{-1}$.

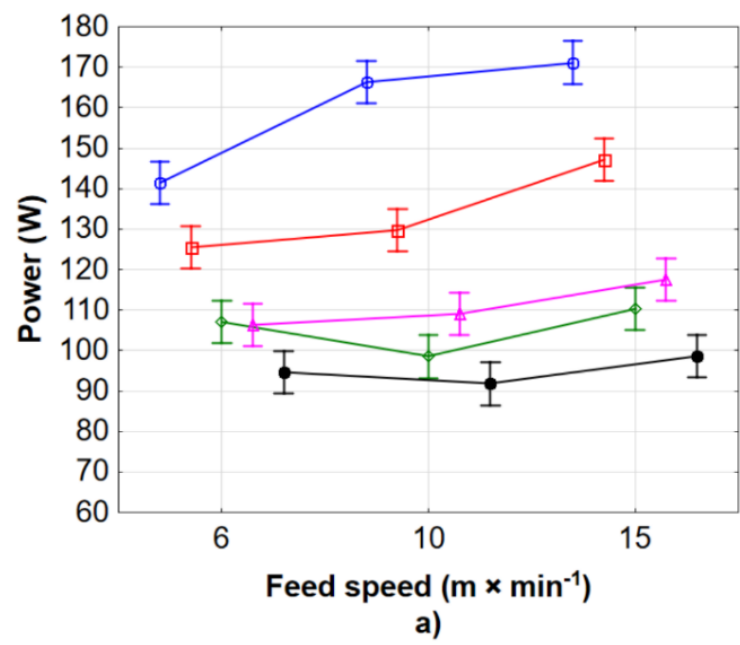

a)

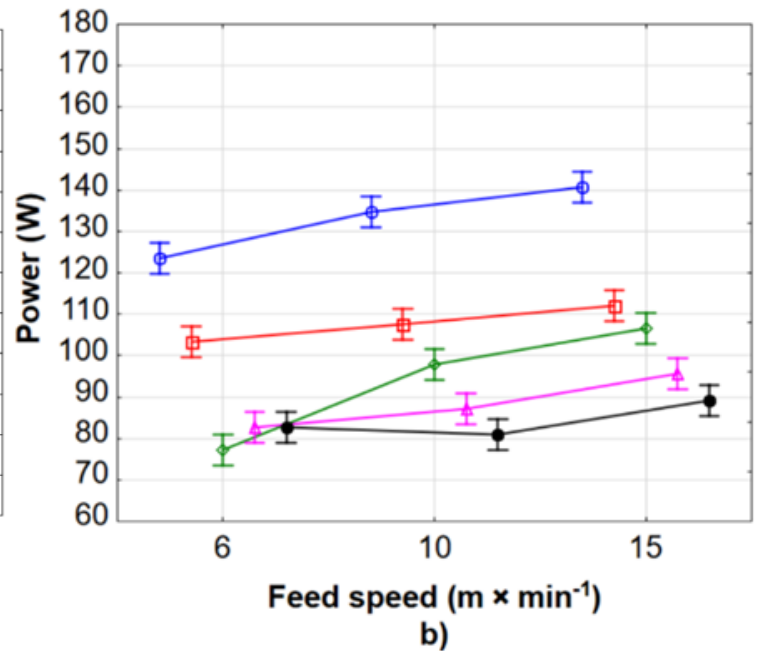

b) 


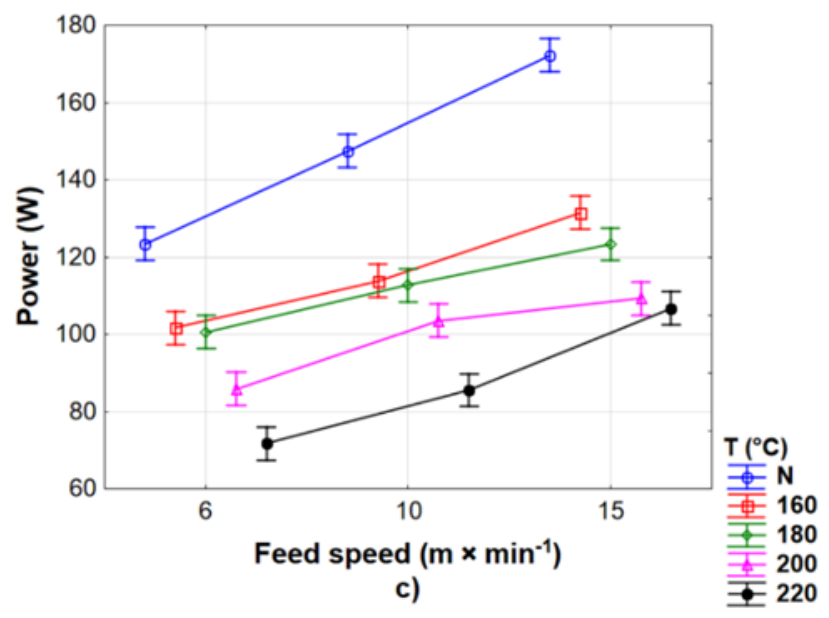

Fig. 11. Analysis of variance of cutting power depending on feed rate and heat treatment temperature for tool set 1 (a), set 2 (b), and set 3 (c)

Factors that influence the reduction in cutting power with respect to temperature are, of course, changes in the chemical composition of the wood and a reduction in density (Hrčka et al. 2020; Maulis 2009; Koleda et al. 2018b).

\section{CONCLUSIONS}

1. In the milling of heat-treated oak wood, it was confirmed that cutting power decreased while modification temperature increased. This was related to a change in the chemical composition and structure of the wood as well as a change in its density. The lowest cutting power $(89.07 \mathrm{~W})$ was measured at $220^{\circ} \mathrm{C}$, and the highest cutting power (146.8 W) was observed for native wood. Therefore, the qualitative parameters of the treated surface and the product should be considered.

2. The surface treatment of the cutting tool affected the cutting power. The lowest energy consumption for milling $\left(84.24 \mathrm{~W}\right.$ for $220^{\circ} \mathrm{C}$ ) was measured using knives from HSS $18 \% \mathrm{~W}$ steel with AlTiCrN coating. The highest values $(159.6 \mathrm{~W}$ with an untreated sample) were recorded for milling with knives induction hardened from material 19573.

3. The cutting speed affected the cutting power. Increasing the cutting speed increased cutting power by increasing the cutting force. The lowest cutting power $(61.15 \mathrm{~W})$ was

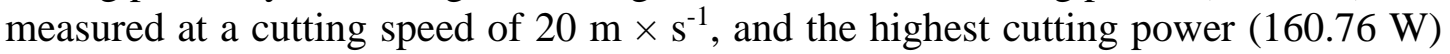
was measured at a cutting speed of $60 \mathrm{~m} \times \mathrm{s}^{-1}$.

4. The rake angle influenced the cutting power. The rake angle increased, resulting in decreased cutting power. The lowest cutting power $(83.30 \mathrm{~W})$ was measured at a rake angle of $30^{\circ}$, and the highest cutting power $(130.37 \mathrm{~W})$ was measured at a rake angle of $15^{\circ}$.

5. Feed rate influenced the cutting power. Increasing the feed rate resulted in an increased cutting power. The lowest cutting power $(101.82 \mathrm{~W})$ was measured at a feed rate of 6 $\mathrm{m} \times \mathrm{min}^{-1}$, while the highest cutting power $(122.11 \mathrm{~W})$ was observed at a feed rate of $15 \mathrm{~m} \times \mathrm{min}^{-1}$. 


\section{ACKNOWLEDGMENTS}

The paper was written within the project: VEGA 1/0315/17, "Research of relevant properties of thermally modified wood at contact effects in the machining process with the prediction of obtaining an optimal surface", the project of Internal Project Agency No. $2 / 2019$, and the "Impact of selected technological, tool and material factors on the surface finish quality and energetic intensity at plane milling of thermally modified spruce wood," as well as with the support of project APVV 17/0456 "Thermal modification of wood with water vapor for purposeful and stable change of wood color."

\section{REFERENCES CITED}

Aytin, A., Korkut, S., and Çakıcıer, N. (2019). "The effect of ThermoWood method heat treatment on physical and mechanical properties of Sorbus torminalis," BioResources 14(2), 3289-3300. DOI: 10.15376/biores.14.2.3289-3300

Barcík, Š., and Gašparík, M. (2014). "Effect of tool and milling parameters on the size distribution of splinters of planed native and thermally modified beech wood," BioResources 9(1), 1346-1360. DOI: 10.15376/biores.9.1.1346-1360

Barcík, Š., Kminiak, R., Řehák, T., and Kvietková, M. (2010). “The influence of selected factors on energy requirements for plain milling of beech wood," Journal of Forest Science 56(5), 243-250. DOI: 10.17221/119/2009-JFS

Bengtsson, C., Jermer, J., Clang, A., and Ek-Olausson, B. (2003). Investigation of Some Technical Properties of Heat-treated Wood (Report No. IRG/WP 03-40266), International Research Group on Wood Protection, Brisbane, Australia.

Boonstra, M. J., Van Acker, J., and Pizzi, A. (2007). "Anatomical and molecular reasons for property changes of wood after full-scale industrial heat-treatment," in:

Proceedings of the Third European Conference on Wood Modification, Cardiff, England, pp. 343-358.

Boonstra, M. J. (2008). A Two-stage Thermal Modification of Wood, Ph.D. Dissertation, Ghent University, Ghent, Belgium.

Černecký, J., Koniar, J., and Brodnianská, Z. (2013). "The effect of regulating elements on convective heat transfer along shaped heat exchange surfaces," Chemical and Process Engineering 34(1), 5-16. DOI: 10.2478/cpe-2013-0002

Černecký, J., Brodnianská, Z., Blasiak, P., and Koniar, J. (2017). “The research of temperature fields in the proximity of a bundle of heated pipes arranged above each other," Journal of Heat Transfer-Transactions of The ASME 139(8), 082001, 12 pp. DOI: $10.1115 / 1.4036041$

de Moura, L. F., Brito, J. O., Nolasco, A. M., and Uliana, L. R. (2011). "Effect of thermal rectification on machinability of Eucalyptus grandis and Pinus caribaea var. hondurensis woods," European Journal of Wood and Wood Products 69, 641-648. DOI: $10.1007 / \mathrm{s} 00107-010-0507-\mathrm{x}$

Gaff, M., Kvietková, M., Gašparík, M., Kaplan, L., and Barcík, Š. (2015). "Effect of selected parameters on the surface waviness in plane milling of thermally modified birch wood," BioResources 10(4), 7618-7626. DOI: 10.15376/biores. 10.4.7618-7626

Gunduz, G., Korkut, S., Aydemir, D., and Bekar, I. (2009). "The density, compression strength and surface hardness of heat-treated hornbeam (Carpinus betulus L.) wood," 
Maderas: Ciencia y Tecnología 11(1), 61-70. DOI: 10.4067/S0718221X2009000100005

Hrčka, R., Kučerová, V., Hýrošová, T., and Hönig, V. (2020). “Cell wall saturation limit and selected properties of thermally modified oak wood and cellulose," Forests 11(6), 640, 11 pp. DOI: 10.3390/f11060640

Hrčková, M., Koleda, P., Koleda, P., Barcík, Š., and Štefková, J. (2018). "Color change of selected wood species affected by thermal treatment and sanding," BioResources 13(4), 8956-8975. DOI: 10.15376/biores.13.4.8956-8975

International ThermoWood Association (2003). ThermoWood® Handbook, International ThermoWood Association, Helsinki, Finland.

Ispas, M., Gurau, L., Campean M., Hacibektasoglu, M., and Racasan, S. (2016). "Milling of heat-treated beech wood (Fagus sylvatica L.) and analysis of surface quality," BioResources 11(4), 9095-9111. DOI: 10.15376/biores.11.4.9095-9111

Koleda, P., and Hrčková, M. (2018). "Global and local thresholding techniques for sawdust analysis," Acta Facultatis Technicae 23(1), 33-42.

Koleda, P., Barcík, Š., and Nociarová, A. (2018a). "Effect of technological parameters of machining on energy efficiency in face milling of heat-treated oak wood," BioResources 13(3), 6133-6146. DOI: 10.15376/biores.13.3.6133-6146

Koleda, P., Korčok, M., Barcík, Š., and Il'aš, Š. (2018b). "Effect of temperature of heat treatment on energetic intensity of flat milling of Picea abies," Management Systems in Production Engineering 26(3), 151-156. DOI: 10.1515/mspe-2018-0024

Koleda, P., Barcík, Š., Korčok, M., and Jamberová, Z. (2020). "Effect of temperature of heat treatment of oak wood and technological parameters of milling on energetic efficiency when planar milling," Acta Facultatis Technicae (25)1, 9-20.

Korčok, M., Koleda, P., Barcík, Š., and Vančo, M. (2018). "Effects of technical and technological parameters on the surface quality when milling thermally modified European oak wood," BioResources 13(4), 8569-8577. DOI: 10.15376/biores.13.4.8569-8577

Korčok, M. (2020). Analysis of Effect of Heat-treated Wood Technology on Energetic Efficiency and Creation of Surfaces of Machining, Ph.D. Thesis, Technical University in Zvolen, Zvolen, Slovakia.

Krauss, A., Piernik, M., and Pinkowski, G. (2016). "Cutting power during milling of thermally modified pine wood," Drvna Industrija 67(3), 215-222. DOI: 10.5552/drind.2016.1527

Kubš, J., Gaff, M., and Barcík, Š. (2016). "Factors affecting the consumption of energy during the milling of thermally modified and unmodified beech wood," BioResources 11(1), 736-747. DOI: 10.15376/biores.11.1.736-747

Kubš, J., Gašparík, M., Gaff, M., Kaplan, L., Čekovská, H., Ježek, J., and Štícha, V. (2017). "Influence of thermal treatment on power consumption during plain milling of lodgepole pine (Pinus contora subsp. murrayana)," BioResources 12(1), 407-418. DOI: 10.15376/biores.12.1.407-418

Liu, Z., Zhang, W., Liu, L., and Xiao, Z. (2017). "Measuring and calculating the computer numerical control lathe's cutting power and total electric power consumption based on servo parameters," Advances in Mechanical Engineering 9(9), 1-11. DOI: $10.1177 / 1687814017723293$

Maulis, V. (2009). Technologie a Zhodnoceni Vybraných Vlastností Dřeva Modifikovaného Teplem [Production Technology and Evaluation of Thermal 
Modified Wood], Master's Thesis, Czech University of Life Sciences, Prague, Czech Republic.

Mickovic, A., and Wouters, M. (2020). "Energy costs information in manufacturing companies: A systematic literature review," Journal of Cleaner Production 254, Article ID 119927. DOI: 10.1016/j.jclepro.2019.119927

Moradnazhad, M., and Unver, H. O. (2017). "Energy consumption characteristics of turnmill machining," The International Journal of Advanced Manufacturing Technology 91, 1991-2016. DOI: 10.1007/s00170-016-9868-6

Niemz, P., Hofmann, T., and Rétfalvi, T. (2010). "Investigation of chemical changes in the structure of thermally modified wood," Maderas: Ciencia y Tecnología 12(2), 6978. DOI: $10.4067 / \mathrm{S} 0718-221 \times 2010000200002$

Očkajová, A., and Banski, A. (2009). "Characteristic of dust from wood sanding process," in: Wood Machining and Processing - Product Quality and Waste Characteristics, WULS-SGGW Press, Warsaw, Poland, pp. 116-141.

Očkajová, A., Kučerka, M., Banski, A., and Rogoziński, T. (2016). "Factors affecting the granularity of wood dust particles," in: Proceedings of the Chip and Chipless Woodworking Processes $11^{\text {th }}$ International Science Conference, Terchová, Slovakia, pp. 137-144.

Požgaj, A., Chovanec, D., Kurjatko, S., and Babiak, M. (1997). Structure and Properties of Wood, Príroda, Bratislava, Slovakia.

Shi, K. N., Ren, J. X., Wang, S. B., Liu, N., Liu, Z. M., Zhang, D. H., and Lu, W. F. (2019). "An improved cutting power-based model for evaluating total energy consumption in general end milling process," Journal of Cleaner Production 231, 1330-1341. DOI: 10.1016/j.jclepro.2019.05.323

Sudarsan, R., Sriram, R. D., Narayanan, A., Sarkar, P., Lee, J., Lyons, K. W., and Kemmerer, S. J. (2010). "Sustainable manufacturing: Metrics, standards, and infrastructure - Workshop summary," in: Proceedings of the 2010 IEEE Conference on Automation Science and Engineering (CASE), Toronto, Canada, pp. 144-149.

Tu, D., Liao, L., Yun, H., Zhou, Q., Cao, X., and Huang, J. (2014). "Effects of heat treatment on the machining properties of Eucalyptus urophylla $\times$ E. camaldulensis," BioResources 9(2), 2847-2855. DOI: 10.15376/biores.9.2.2847-2855

Vasilko, K. (2007). Analytic Theory of Chip Manufacturing, Faculty of Manufacturing Technology of the Technical University of Košice, Prešov, Slovakia.

Zein, A. (2012). Transition Towards Energy Efficient Machine Tools, Springer Science+Business Media, Berlin, Germany.

Article submitted: September 16, 2020; Peer review completed: Peer review completed: November 15, 2020; Revised version received and accepted: November 22, 2020; Published: November 24, 2020.

DOI: $10.15376 /$ biores.16.1.515-528 